\title{
IN SEARCH OF PERFECTA: THE CONUNDRUM OF INCORRECTLY PRICED GOODS UNDER THE CONSUMER PROTECTION ACT 68 OF 2008
}

\section{Introduction}

In spite of the sea change over the past sixty-odd years in the way we shop, from a personal interaction with the local shopkeeper to a cashierless selfcheckout, and the billions of transactions that take place daily in stores and supermarkets around the world, there is a dearth of legal precedent regarding the legal mechanics of these transactions. This is particularly so as far as determining the very important practical issue of at what point the sale is perfecta (irrevocably concluded) is concerned. For example, a consumer receives a catalogue from a well-known store in which a flat screen television is advertized on special for R599. Well knowing that such television sets are normally sold for over R6000 the consumer rushes off to purchase a set only to be faced with a large sign which reads as follows:

"Unfortunately the advertised price was incorrect, the correct price is R5 999.

We apologise for the inconvenience."

A slightly different scenario is where the consumer is only informed of this mistake after she has removed the television set from the shelf and taken it to the cashier who proceeds to ring up the price of R5 999. When the consumer points out that this is not the advertised price the cashier informs her that a mistake was made and that in fact R5 999 is the correct price. Is there a point in time when the supplier, despite a mistake, may be bound by the advertised price? (The purpose of this article is to consider the point in time when the contract is regarded as perfecta. The scenario set out above may also constitute bait-advertising. This is an issue which we intend to consider in our next article.) It is against this backdrop that we attempt to provide some guidance to those who are obliged to comply with the provisions of the Consumer Protection Act (68 of 2011, hereinafter "the CPA"), relating to displayed prices.

In doing so, we shall consider the extent to which the Roman-Dutchbased common law has been influenced by English Law in this area of consumer protection. Reference will be made to the principles of the common law regarding the formation of a contract (particularly the point at which the contract comes into effect), quasi consent and mistake as well as relevant foreign precedent. We shall then deal with the changes brought about by the CPA. 


\section{Common-law position}

\section{Origin and development}

In early Roman law, the form of the agreement was more important than the intention of the parties. Each type of contract had its own special rules and requirements regarding the formalities or acts that had to be performed. Any deviation from the formalities rendered the agreement void (Glover "Metus in the Roman Law of Obligations" 200410 Fundamina : A Journal of Legal History 31 33; and Van Niekerk "Orality in African Customary- and Roman Law of Contract: A Comparative Perspective" 201122 De Jure 364 369). During the classical period of Roman law, it was not the agreement inherent in the transaction that created the obligation, but the res or act of handing over the subject matter of the transaction (Christie and Bradfield Christie's Law of Contract in South Africa 6ed (2011) 5). By the post-classical period, meaning had largely triumphed over form (Tiersma "The Language of Offer and Acceptance: Speech Acts and the Question of Intent" $198674 \mathrm{Cal} L R$ 189 191). This was taken further in Roman-Dutch Law which, influenced by Canon Law and the Germanic concept of honouring promises, treated every agreement made seriously and deliberately as a contract (Christie and Bradfield Christie's Law of Contract in South Africa 5). The South African law of contract is largely Roman-Dutch law based with some cross-pollination with English contract law (Christie and Bradfield Christie's Law of Contract in South Africa 12-24), with the result that agreement by consent is regarded as the foundation of contract (Christie and Bradfield Christie's Law of Contract in South Africa 24). A fundamental general principle that is associated with this is that parties should comply with contractual obligations that have been freely and voluntarily undertaken (Barkhuizen v Napier 2007 (5) SA 323 (CC) par 57). It is important to be able to establish exactly when a particular contract comes into effect because this is the point of no return.

\section{The intention of the parties: Offer and acceptance}

An agreement comes into effect when there is consensus, or a meeting of the minds (Joubert $v$ Enslin 1910 AD 37-38). The technique used to determine whether an agreement has been reached is to look for evidence of an offer and acceptance of that offer (Christie and Bradfield Christie's Law of Contract in South Africa 30). The offer-and-acceptance formula, developed in the $19^{\text {th }}$ century, identifies the moment of formation when the parties are of one mind (Pachecker Nafa's Blue Book: Legal Terminology, Commentaries, Tables and Useful Legal Information (2010) 205). However, it is not always possible to reduce every contract to a simple situation of offer and acceptance and in some cases a fiction is imported into the transaction for purely doctrinal reasons (see Van der Heever JA in Estate Breet $v$ PeriUrban Areas Health Board 1955 (3) SA 523 (A) 532E; and Greig and Davis The Law of Contract (1987) 246, point out that the rules of offer and acceptance are merely an aid to analysis and may sometimes prove inconclusive). It is generally accepted that trying to fit all contractual negotiations into the "rigid boxes of offer and acceptance can be rather artificial" (Stone and Devenney Text, Cases and Materials on Contract Law 
(2013) 56, quoting from New Zealand Shipping Co Ltd v A M Satterthwaite \& Co Ltd (The Eurymedon) [1975] AC 154 167).

There is a risk that once pure fictions are resorted to in dealing with rapidly permutating technology, the law will deteriorate into farce. This is already arguably the case where a merchant advertises or displays goods for sale, as was the case in Crawley $v$ Rex (1909 TS 1105). In this case a shopkeeper advertised a particular brand of tobacco at a cheap price to attract the public on a placard outside his shop. One customer refused to leave the premises when the shopkeeper declined to sell more of the tobacco to him after he returned on a second occasion. In his defence to a subsequent charge of statutory trespass, the customer claimed he was entitled to be in the shop as he was accepting the shopkeeper's offer. The court held that no contract had arisen because the advertisement did not constitute a binding offer that the customer could accept but was merely an announcement of the shopkeeper's intention to sell at the advertised price (Crawley v Rex supra 1108).

It is important to note that no authority was relied upon to arrive at the decision and that it is generally accepted that it followed English law. (See Du Plessis Display of Goods for Sale, Advertisements and the Consumer Protection Act 68 of 2008 Paper presented at conference on consumer law: 14th International Association of Consumer Law Conference, University of Sydney in July 2013. This paper has been accepted for publication in the 2015 SALJ.) The same principle applies where price tickets are attached to goods on shelves (Christie and Bradfield Christie's Law of Contract in South Africa 43). The English-law position with regard to items displayed for sale in a self-service shop is found in Pharmaceutical Society of Great Britain $v$ Boots Cash Chemists (Southern) Ltd ([1953] 1 QB 401 (CA)). Boots Cash Chemists was charged with infringing a statute that required that the sale of poison be supervised by a registered pharmacist after two customers bought medicines containing controlled substances from it. The customers selected goods from the "self-service" section (a novel concept at that time) and paid for them at the till. This was situated close to where the registered pharmacist was.

The Pharmaceutical Society was unsuccessful in its contention that the sale took place when the customer took an article from the shelf and put it in the shopping basket, which did not happen under the supervision of the pharmacist. The court held that the self-service system did not amount to an offer to sell, but was merely to an invitation to the customer to make an offer to buy. Such offer was accepted at the cashier's desk. The court held (without reference to authority) that the precise moment at which the transaction is concluded is when the customer tells the assistant that he wants a selected item and the assistant says "That is all right", and the price is accepted (Pharmaceutical Society of Great Britain v Boots Cash Chemists (Southern) Ltd supra 405-406). The sale therefore took place under the supervision of a registered pharmacist.

In this regard the observation made by Atiyah (Atiya and Smith Atiyah's An Introduction to the Law of Contract 6ed (2006) 44) is apposite:

"In the particular case of self-service shops, legal methods of reasoning probably mean that the law is today out of touch with modern social 
conditions, and also with public attitudes. Most people would probably be surprised to discover that a shop keeper is not obliged to sell an article at the price indicated if a customer offers to pay for it, and this public attitude is confirmed by the fact that such behaviour by a shopkeeper would today probably constitute an offence under ... consumer protection legislation."

Clement JA, in the Appellate Division of the Alberta Supreme Court case of $R \vee$ Dawood ([1976] 1 WWR 262), declined in a dissenting judgment to follow Boots Cash Chemists. In the Dawood case, a woman changed the price tag on clothing, took it to a cashier, and paid the lower price. She was convicted of theft. The majority of the Appellate Division quashed the conviction of theft and held that the woman was making an offer, which the cashier accepted on the store's behalf (it was argued and accepted by the court that she should have been charged with offence of false pretences). In his dissenting judgment, Clement JA, stressed the realities of how selfservice stores operate. The common feature is that there are no clerks to wait on customers. Goods are displayed on shelves or racks and on each item the price of the article is affixed. In Clement JA's view, this constituted an offer by the store which was accepted by the customer when he actually carried the goods to the cashier and paid the price. The role of the cashier was simply to receive the price and bag the goods ( $R v$ Dawood supra 270; and this is also the approach suggested by Stone and Davenney The Modern Law of Contract 10ed (2013) 38).

This approach is perhaps more in line with what people would expect the law to be and it accords with the American common-law approach as enunciated in Lasky v Economy Grocery Stores (319 Mass. 224, 65 N.E. (2d) 305, 163 A.L.R. 235 (1946)). This case involved a person who was injured when a bottle of tonic exploded whilst she was selecting the bottles off the shelf. Her cause of action was based on breach of warranty in a contract of sale. The court held that a contract of sale would have been concluded only when the customer accepted the offer to sell (made by displaying the goods on the shelf) by taking the goods to the check-out. Until that time the seller had not assumed any contractual obligations with the customer to sell the tonic. (The outcome was the exact opposite in a later American exploding-bottle case, Barker v Allied Supermarket, 596 P.2d 870 (Okla. 1979). This case was decided on the basis of a statute that provided for acceptance in any of three ways: (1) by the act of delivering the goods to the check-out counter and paying for them; (2) by the promise to pay for the goods as evidenced by their physical delivery to the check-out counter; or (3) by the promise to deliver the goods to the checkout counter and to pay for them there as evidenced by taking physical possession of the goods by their removal from the shelf http://law.justia.com/cases/oklahoma/supremecourt/1979/48031.html (accessed 2014-07-02)).

The French have a similar approach but it seems that the contract is concluded when the customer indicates an intention to purchase, such as by placing the goods in the shopping basket. This is illustrated in the case of Soc.des Eaux de Vittel v Dehen Soc. Supermag Rennes GP ([1962] I 135). This case also involved an exploding bottle. The customer bought a claim under the Code Civil for breach of contract arising from injuries suffered after she had selected a bottle of Vittel-Delight at a self-service market and it exploded when she was at the checkout counter waiting to pay. (As reported 
by Bartsch International Aviation Law: A Practical Guide (2013) http:books. google.co.za/books?id=PZM7xli7LKEC\&pg=PT139\&lpg=PT139\&dq=boots $+\mathrm{i}$ nternational+aviation+law\&source $=$ bl\&ots=SldkTNy4jB\&sig=HCzdnsBo_xb3 $\mathrm{d} 4 \mathrm{H}$ 0as5KDF3hZE4\&hl=en\&sa $=\mathrm{X} \& \mathrm{ei}=\mathrm{VnnNU}$ 7quAsv-PJOjgeAB\&ved=0CC Q6AEwAA\#v=onepage\& $q=$ boots\%20international\%20aviation\&20law\& $f=f a l$ se (accessed 2014-07-02).) In this case, the customer was successful in her claim.

In practice it is important to be able to pinpoint the exact point at which the contract is concluded. This is the point of no return when the supplier cannot refuse to sell the goods at a particular price. That point is reached when the agreement is perfecta, which we now consider.

\section{Perfecta: Nothing further required}

The sale becomes perfecta once there is agreement on the merx (the thing sold) and the pretium (price) and any condition, resolutive or suspensive, has been fulfilled. Once the seller promises to deliver a thing to the buyer and the latter agrees to pay a certain price, agreement is reached and that alone constitutes the sale - neither delivery nor payment is necessary before the sale is concluded (Visser, Pretorius, Sharrock and Van Jaarsveld Gibson: South African Mercantile and Company Law 8ed (2004) 110). These two elements relate rather to the performance of the contract and are not essential to constitute a sale (Chanock v Barnard 1921 OPD 207; see also Nimmo v Klikenberg Estates Co. Ltd 1904 TH 310 314; and Visser et al Gibson: South African Mercantile and Company Law 110-113).

Difficulties arise when either the offer or the acceptance is not express and verbal but tacit, that is, the intention is communicated by conduct unaccompanied by words (Christie and Bradfield Christie's Law of Contract in South Africa 84). Sometimes the act of paying for goods or delivering them may provide the necessary proof of that intention. An example is the roadside news vendor who holds out a folded newspaper to passing motorists and the motorist who holds out the correct price for the newspaper as he drives past the vendor. Following Crawley $v$ Rex, the offer of payment would constitute the offer and the simultaneous acceptance of the money and handing over of the newspaper paper the acceptance.

Christie argues that with the sale of goods by means of a vending machine, the rule is reversed as the controller of the machine must be taken to be making the offer because he has put it out of his power to exercise any choice in the conclusion of the contract, and the customer accepts the offer by his conduct when he inserts his coin (Christie and Bradfield Christie's Law of Contract in South Africa 92).

These examples illustrate that difficulties arise in the search for the intention of the parties. So, although the basis of a contract is agreement between the parties, the law does not establish agreement by considering the subjective intention of the parties. Instead, it focuses on the manner in which the parties have manifested their intentions (Christie and Bradfield Christie's Law of Contract in South Africa 24-30). This objective approach has come to be known as the doctrine of quasi-mutual assent or the reliance theory of contract. 


\section{Quasi-mutual assent}

This doctrine was clearly enunciated by Blackburn $\mathrm{J}$ is the oft-quoted case of Smith v Hughes ((1871) LR 6 (QB) 597 607):

"If whatever, a man's real intention may be, he so conducts himself, that a reasonable man would believe that he was assenting to the terms proposed by the other party, and that other party upon that belief enters into the contract with him, the man so conducting himself would be equally bound as if he had intended to agree to the other party's terms."

As a result of the application of this doctrine, a party is not entitled to claim that their real intention was not understood by the other party and thereby escape from the transaction. The doctrine thus protects parties who would otherwise not be able to dispute the other contracting party's denial of their "true" intention. Without it, it would be difficult for commerce to proceed at all: All kinds of mental reservations, of careless unilateral mistakes of unexpressed conditions and the like would become relevant and no party to any contract would be safe (Irvin and Johnson (SA) Ltd v Kaplan 1940 CPD 647651 ). However, when a party relies on a representation that an offer has been made their belief must be reasonable. A person's belief will not be reasonable and he cannot hold the other person to a contract where he was aware that an error had been made (see, eg, Sonap Petroleum (South Africa) (Pty) Ltd v Pappadogianis 1992 (3) SA 234 (A)), where he ought to have been aware that an error had been made (see, eg, Horty Investments (Pty) Ltd v Interior Acoustics (Pty) Ltd 1984 (3) SA 537 (W)), or where because of his conduct the other party was induced into making an error (see, eg, Dlovo v Brian Porter Motors Ltd t/a Port Motors Newlands 1994 (2) SA 518 (C)). An oft quoted example of a unilateral mistake is found in the case of Maritz $v$ Pratley ((1894) 11 SC 345). At an auction sale one lot, a mirror, was placed on top of another lot, a mantelpiece. When the mantelpiece was knocked down to Pratley, he claimed that it should come with the mirror. The court held that it was an honest mistake and accordingly, that there was no sale. It is significant for the present purposes that the auctioneer was not held to the sale of both lots at the price on just the mantelpiece.

Where, a person is aware of the error and he takes advantage of it, he is said to be "snatching at a bargain". In Sonap Petroleum (South Africa) (Pty) $L t d v$ Pappadogianis, Harms AJA reasoned thus:

\footnotetext{
"All this leads me to the conclusion that, as a matter of probabilities, the respondent was not misled by the appellant to believe that it was its intention to amend the period, but, on the contrary, that he was alive to the real possibility of a mistake and that he had, in the circumstances, a duty to speak and to enquire. He did not but decided to snatch the bargain. That he could not do. There was, therefore, no consensus, actual or imputed, on this issue" (par 25).
}

The Supreme Court of Appeal came to the opposite finding on the facts in Slavin's Packaging (Pty) Ltd v Space Case Products (Pty) Ltd ((683/94) [1996] ZASCA 64) in which an employee had mistakenly transposed the prices of two items when offering them for sale. Smalberger JA illustrated just how narrow the defence of unilateral mistake is: 
"The fact that Slavin appreciated that he was striking a bargain does not mean that he 'snatched' at one in the legal sense. The latter concept denotes an unconscionable act (which the law will not countenance) in deliberately seeking to take advantage of another's known mistake (I refer, of course, to the case where actual knowledge is present); striking a bargain is a legitimate occurrence frequently encountered in the business and commercial world which the law recognises and enforces." (In Sonap, the court held that actual knowledge was not required but "whether the respondent, objectively speaking, as a reasonable man, should have appreciated the real possibility of a unilateral mistake" (par 25). The mistake must also be material.)

What then, in light of these judgments, would the common-law approach be to the everyday situation of an item being incorrectly priced on the shelf of a self-service store - would the store be bound by that incorrect price? If the display is accepted to be an invitation to treat, the store would be free to reject the customer's offer to buy at the mistaken price. If, however, the display is treated as an offer to sell at the displayed price, the magnitude of the error may be decisive in determining whether the customer, as a reasonable man, should have appreciated the real possibility of a unilateral mistake and not be permitted to benefit from it.

Thus, if the price of a television set was mistakenly displayed as being R4 999 instead of R5 999, on the strength of Slavin's Packaging, the customer may be entitled to accept this as a bargain and the price would be binding. What if the price was instead the more likely error of $R 599$ ? In terms of Sonap Petroleum, the reasonable man would, in the absence of anything else, be alive to the real possibility of a mistake and accordingly have a duty to ensure that was the correct price. This conclusion would be strengthened if the incorrectly priced television set was amongst a number of other identical sets that were correctly priced, but might not hold true if alongside the mistakenly priced set there was a sign saying "never to be repeated bargain" or words to that effect.

That then is a brief overview of the common law pertinent to contracts of sale in a self-service environment. We now consider the extent to which this has been codified or replaced by the CPA.

\section{The CPA}

The CPA, as its name suggests, focuses on the protection of consumers. The only direct reference to the interests of businesses is the mention of a sustainable marketplace for consumer products in the opening statement of the CPA. The Preamble speaks of developing and employing innovative means to protect the interests of all consumers. Reading the preamble as a whole, there seems to be a suggestion that the predicament of consumers was as a result of the discriminatory laws of the past. This would not be an unreasonable supposition on the part of the legislature as far as shoppers are concerned. If one rereads the case law in this area through the lens of the CPA, it is very evident that the courts both here and in England gave scant attention to the interests of the consumers in arriving at their decisions and formulating the rules.

The CPA acknowledges in the Preamble that there will be emerging technological changes, trading methods, patterns and agreements. In a 
departure from tradition, it requires the Tribunal (this is the National Consumer Tribunal established under the National Credit Act, 2005 which deals with matters under the National Credit Act and the CPA) or a court to develop the common law as necessary to improve the realization and enjoyment of consumer rights generally. They can do so by employing innovative means or making innovative orders (Preamble and $s$ $4(2)(b)(i i)(b b))$ and may consider appropriate foreign and international law (s 2(2)(a) and (c)).

It is important to acknowledge that the CPA has made sweeping changes to the common law. The most noteworthy of these and the one most likely to unsettle lawyers with a Roman-Dutch law grounding is the demise of freedom of contract. Part $\mathrm{G}$ of the CPA places significant restrictions on the terms that may be incorporated into a contract (Van Vuuren "Contractual Autonomy and Consumer Rights" 20099 Without Prejudice 38). According to Du Plessis, the main purpose of the CPA marks a clear change from the traditional approach based on contractual autonomy, where the supplier has a right to choose his customers and may therefore simply elect not to sell to a particular customer for whatever reason (Du Plessis paper presented at conference on consumer law 8; and see also Jacobs, Stoop and Van Niekerk "Fundamental Consumer Rights under the Consumer Protection Act 68 of 2008: A Critical Overview and Analysis" 201013 PELJ 302, where the authors consider various provisions of the CPA that make inroads into the common-law position to strengthen the position of the consumer vis-à-vis the supplier).

In terms of the CPA (s 23; this section does not apply to situations where quotes have been provided or internet transactions (s 23(1)); the principles would also not apply to non-CPA transactions and non-retail transactions), a supplier is required to display prices for goods on display (s 23(3)) and, having done so, may not require a customer to pay a price that is higher than the displayed price or any other price displayed (s 23(6); the price may be displayed in a number of different ways including being affixed to the goods or a shelf on which the goods are exposed for sale or published in a catalogue or broschure). This does not apply if:

- the price is determined by regulation (s 23(7));

- the original price is fully obscured by a second displayed price (s 23(8));

- the displayed price is altered, defaced, covered, removed or obscured by an unauthorized person (s 23(10)); or

- the price as displayed contains an inadvertent and obvious error; and

○ the supplier corrects the error; and

- takes reasonable steps in the circumstances to inform consumers to whom the erroneous price may have been displayed of the error and the correct price (s 23(9)(a) and (b), hereinafter as the provisos to $s$ 23(9)).

This section is clearly aimed at providing for the "snatching a bargain" scenario and provides some protection to the honest supplier. It will, however, be argued later that the application of this provision is restricted. 
"Display" is defined as:

[P]lacing, exhibiting or exposing those goods before the public in the ordinary course of business in a manner consistent with an open invitation to members of the public to inspect, and select, those or similar goods for supply to a consumer.

This should be read with section 18(2) which provides that "If any goods are displayed in or sold from open stock, the consumer has the right to select or reject any particular item from that stock before completing the transaction." Unlike section 46(3), which relates to completion of a sale by auctions, section 18 does not define when the transaction involving displayed goods is finalized. This is an oversight and inconsistent treatment of the issue, particularly as section 19(4) describes the circumstances in which a consumer is regarded to have accepted delivery of any goods.

\section{$4 \quad$ Consideration of issues}

From a practical point of view, there are four aspects of section 23 that require consideration:

(1) Does section 23(6) require a supplier to sell at the lowest displayed price or does it merely prohibit the supplier from selling at the higher price?

(2) Does the section change the common-law rule regarding offer and acceptance set out in Crawley $v$ Rex; and, most importantly,

(3) if the seller is obliged to sell at the advertised price, at what point in the process is the contract perfecta?

(4) Is it is still possible to raise "snatching a bargain" in a CPA environment?

\section{Obliged to sell at the lowest displayed price?}

It is necessary to decide whether section 23(6) merely creates an obligation upon the supplier, the contravention of which might lead to the imposition of a fine (this is the view expressed in Sharrock Business Transactions Law 8 ed (2011) 631-632), or does it impose an obligation upon the supplier to sell the item to the consumer at the lowest displayed price?

Du Plessis (paper presented at consumer conference 11) argues that the supplier is bound by the displayed price by reasoning that this can be inferred from the words "the seller is not bound" used in the exceptions contained in sections 23(9)-(10). Bracher reaches the same conclusion but takes a different approach (Bacher Consumer Protection Act opinion provided to the office of the Consumer Goods and Services Ombud (201404-11) 4). He reasons that, if a supplier is not bound by the provisos to section 23(9), the corollary must be true, namely that the supplier is bound if the displayed price is not inadvertent but deliberate or if it is not an obvious error.

Another way of looking at it is to read the section with section 115, which refers to a person who institutes a claim in a civil court for the assessment of the amount or awarding of damages for loss suffered as a result of prohibited conduct, or dereliction of required conduct. The significance of 
this section is, that once the Tribunal has found something to be a prohibited or required conduct, the consumer is entitled to base a civil claim for damages on the relevant section. In other words, the breach of the statutory duty gives rise to a legal right. In this case the consumer has the right to purchase the goods at the displayed price.

\section{Change the common law?}

The traditional presumption or rule of statutory interpretation is that Parliament does not intend to change the common law more than is necessary as provided in express terms or is a necessary inference from the provisions of the enactment. (Grobler v Msimanga [2008] 3 All SA 549 (W) 136; Mills v Starwell Finance (Pty) Ltd 1981 (3) SA 84 (N) at 87B-D. The presumption emerged in a period when the body of statute law was small and statutory intervention was generally narrowly directed to quite specific rules and practices: Spigelman The Principle of Legality and the Clear Statement Principle Paper presented at the New South Wales Bar Association Conference Working with statutes, Sydney, 18 March 2005.) The CPA not only expressly requires that the interests of the consumer are to be given preference but goes further to require the courts and Tribunal to develop the common law as necessary to improve the realization and enjoyment of consumer rights generally.

This merely makes official what the courts have been doing anyway in order to keep the law relevant to the rapidly changing retail environment. (As was noted above, rules were formulated in the cases of Crawley $v$ Rex and Boots Cash Chemists without reference to authority. The simple reason for this was that there was no authority.) Reference to offer and acceptance and the intention of the parties becomes increasingly artificial in an electronic age. No negotiation takes place in modern departmental stores. There is seldom conversation beyond a greeting, being asked if one is paying with cash or credit card or if one requires a bag. Section 23 does not differentiate between self-service stores and those with sales assistants who select the goods from where they are stored for the customer. It would be absurd to attempt to clothe an order for replenishments placed via the internet by a barcode/radio frequency identification scanning smart fridge with a supermarket's server computer (this technology already exists "The Smart Fridge of the Future" 15 January 2014 Daily Mail (UK)) with the attributes of a trader and customer haggling over a price at the Casbah.

The time has perhaps come to turn in full circle and revert to the Romanlaw approach of placing "store" on the form of the transaction and abandoning all attempts to glean the intentions of the parties. This would fit well with the increased use of technology with the likes of vending and parking-ticket cases and be in accordance with the generally utilitarian approach of the CPA.

Until a bold judicial officer takes that step, we still need to determine whether the display of goods is an offer to treat or an offer that becomes binding upon acceptance by the consumer. The inclusion of reference to an "open invitation to members of the public to inspect, and select ..." in the definition of display does not point definitively in either direction. Further, the 
CPA does not expressly throw any light on the matter. It does, however, refer to the conclusion of a transaction and being bound, which is clearly the legal-state equivalent to perfecta in the common law. It would seem then that the CPA has abandoned or ignored the concepts of offer and acceptance entirely in so far as they relate to evidencing the intention of the parties to contract in a retail environment.

It is important to bear in mind that Crawley $v$ Rex dealt with a placard placed outside a shop, which is more akin to an advertisement than a displayed price, and was decided before the advent of self-service stores and there has been no more recent decision by our courts in this area. The Boots Cash Chemists decision, which in any event was obiter as it related to criminal charges (Stone and Davenney The Modern Law of Contract 10ed (2013) 38) (the same can be said of Crawley $v$ Rex) is not binding on our courts. It is submitted that even without the legislative power conferred upon the courts by the CPA, they are, in the absence of authority, free to arrive at an appropriate conclusion and give the necessary guidance in this area.

Bracher's (opinion provided to the office of the Consumer Goods and Services Ombud) reasoning referred to above, namely that the corollary to the provisos to section 23(9) is that the supplier is bound if the displayed price is not inadvertent but deliberate or if it is not an obvious error, is compelling. It can be extended to the conclusion that even if goods are displayed with a price that is not an error, the supplier is nevertheless bound. It would otherwise be illogical to say the display of goods with a price amounts to an offer only if there was an inadvertent and obvious error in the price and the provisos to section 23(9) have not been fulfilled.

This approach accords with the CPA enjoinder to favour the consumer if there is ambiguity and does not give rise to the situation feared in Crawley $v$ Rex of multitudes of customers converging on a supplier who is out of stock because, unlike an advertisement, a displayed price only applies to the actual stock on display. There is no obligation to replenish the stock once it runs out.

In conclusion, the CPA has brought South African law regarding every day retail transactions in line with the approach taken in French and American law that is, the mere display of goods (in a retail environment) amounts to a binding offer and not an invitation to treat.

\section{Point of completion/perfecta}

The import of section 23(9) is that the supplier is bound by an inadvertent and obvious error unless the supplier corrected the error in the displayed price and took reasonable steps in the circumstances to inform consumers of the error. It is therefore essential to determine the point in the dealing until which the supplier can take these steps, and after which the supplier is bound regardless. In the common law, this would be when the contract is perfecta.

As noted above, the CPA is silent on when a transaction is concluded. It cannot be the same as the common-law position, assuming our courts follow the Boots Cash Chemists finding (this is by no means a certainty as the 
decision was made at the dawn of the electronic age and was in respect of a crime rather than a contract) that the sale is concluded when the cashier accepts the price, as this would mean that the concluding act or acceptance would be by the seller. If it is the customer who is accepting the offer, as is suggested in the previous section above, the transaction must be concluded at some time prior to the acceptance of payment.

The possibilities are:

- When the total price has been rung up and the customer tenders payment;

- when the price of the disputed item is rung up at the till;

- when the customer places the goods on the check-out counter;

- when the customer arrives at the check-out counter;

- when the customer takes the goods off the shelf and places them in the basket or trolley.

The first possibility can be excluded on the grounds that payment relates to the performance of the contract rather than when it is concluded or perfecta. It is unlikely in any event that the consumer would tender payment of the disputed amount.

There are difficulties associated with treating the placing of the item in one's basket as acceptance, for example, the consumer is then unable to change his mind (this was the concern of Romer LJ in the Pharmaceutical Society of Great Britain v Boots Cash Chemists (Southern) Ltd supra 408). So the last possibility on the list can also be excluded. To decide which of the other possibilities is the better position, one needs to consider the practicalities of the process.

In practice, the supplier or its servant, the till operator, would become aware of the error only in the price at the point it was rung up at the till. If it was sufficient for the purpose of the first proviso to section 23(9) for the till operator to say "The correct price is R X, I cannot sell the item to you at the incorrectly marked price of $\mathrm{R} Y$ ", that would mean that the supplier would never be bound by an obvious error in price, rendering the section redundant. This would be contrary to the presumption that legislation does not contain futile or nugatory provisions (Ex Parte The Minister of Justice: In re $R v$ Jacobson and Levy 1931 AD 466).

In order to give effect to the section, it is necessary to hold that the transaction is concluded before the price is rung up on the till. The most logical and workable conclusion is that it happens when, where appropriate, the consumer takes the selected goods out of the trolley or basket and places them on the counter (the third possibility) (this approach is supported by Kahn "Some Mysteries of Offer and Acceptance" 195572 SALJ 246 252). By so doing, the consumer is tacitly communicating, "I accept these goods at the prices displayed on or next to them". Unless any of the other of the exceptions exists, the sale becomes binding upon the supplier at that point. It is then, armed with the knowledge of the error, that the supplier can take steps to correct the displayed price and inform subsequent customers of the error before they accept the offer at the displayed price. 
Steps that might be considered reasonable in informing customers include: withdrawing the goods from sale, fixing the correct price or label on a shelf, and then making the product available for sale again; putting up notices at the affected stores (such as the one given in the example at the outset of this article) or making an announcement over the public-address system.

It remains to consider whether, irrespective of the point at which the transaction is perfecta, the supplier may not still claim that it has made an obvious error and the customer is accordingly improperly trying to snatch a bargain.

\section{$44 \quad$ Snatching a bargain}

It is necessary to determine whether the common-law defence of snatching a bargain has been displaced by section 23(9), which states that the supplier is not bound by an inadvertent and obvious error in the price provided it corrected the error and takes reasonable steps to inform consumers of the error. In order to do so, one needs to analyse the section as a whole.

Read as a whole, section 23 provides that a supplier may not charge the higher price unless the price is determined by regulation; the original price is wholly obscured by a new price; there is an inadvertent and obvious error; or there was an unauthorized alteration of the price (s 23(6) read with s 23(7)(10)). This is surely a closed list, so section 29(9) is implicitly intended to replace the common law regarding snatching a bargain. It is difficult to see how any other conclusion can be reached, especially that snatching at a bargain can be relied upon instead of section 29 (9).

Returning to the example of the television set with a price of R5 999, if it has a display price of R4 999, this may have been inadvertent but it cannot be said also to be obvious. Thus the subsection does not apply and the price is binding. If, however the incorrectly displayed price was R599, this is both obvious and, in the absence of any indication to the contrary, inadvertent. As soon as the customer wheels the television set on the trolley up to the till, the supplier is bound by the displayed price on that particular transaction. This is because that is when the transaction is perfecta. It follows that it is then too late for the till operator to say "Sorry, that price is incorrect and I cannot sell it to you at that price." However, having been informed that the price is incorrect, the consumer cannot insist on being supplied with additional sets at that price. Subsequent customers would also benefit from the incorrect price unless or until such time as the supplier corrected the error in the displayed price and has taken reasonable steps to inform consumers of the error.

The fact that the supplier may suffer a loss as a result of the operation of section 29(6) is not without precedent in our law. In Kwa Mashu Bakery Ltd v Standard Bank of South Africa Ltd (1995 (1) SA 377 (D)), it was held that a supplier who voluntarily participates in an activity must bear the cost of safeguarding against the risks created by such involvement (Kwa Mashu Bakery Ltd v Standard Bank of South Africa Ltd supra 394G-395G). Under the CPA, there are restrictions on a supplier passing on its operational risks to the consumer (s 48(1)(c) and 49(1)). In many instances the risk is 
specifically passed to the supplier. For example, the risk of accidental damage to displayed goods (s 18); the risk of returning unsolicited goods (s 20(5)) and the risk of goods on lay-by (s 62(1)(b)) is borne by the supplier and may not be passed to the consumer.

In order to reduce the risk of errors, suppliers can:

- ensure that tills are capable of ringing up displayed prices and are updated as prices advertised and displayed change;

- appoint a specific employee to be responsible to check for price errors in displays at regular intervals;

- ensure that all advertising materials such as catalogues and brochures are carefully checked after printing and that, if there are errors in the displayed prices, reasonable steps (large signs) are taken to alert consumers to the correct prices before they have an opportunity to remove them from the shelves and take them to the till.

\section{$5 \quad$ Conclusion}

The CPA has brought about far-reaching changes to the common law in order to level the playing fields between suppliers and consumers. Further, the CPA empowers the Tribunal and the courts to make innovative orders and align the common law to the objects of the CPA. This will enable the courts to hold that the display of goods in a self-service setting equates to a binding offer on the part of the seller to sell at the price displayed. The CPA even enables the courts to dispense with the outdated concepts of offer-andacceptance and place "store" rather on the form of the transaction. It is argued that the transaction reaches the stage of perfecta or conclusion when the consumer reaches or places the goods on the check-out counter, and at that point the sale at the advertised price is binding even if the price is an inadvertent and obvious error, but not if reasonable steps had already been taken to inform the consumer of the error or if the price was altered without authorization or wholly obscured with a new price.

Neville Melville

Advocate of the High Court of South Africa Ombudsman for Consumer Goods and Services Honorary Research Fellow of the University of KwaZulu-Natal, Durban

and

Tanya Woker University of Kwazulu-Natal, Durban 